ERIA Discussion Paper Series

\title{
The Role of China, Japan, and Korea in Machinery Production Networks*
}

\author{
Ayako OBASHI \\ University of Wisconsin and Keio University \\ Fukunari KIMURA \\ Keio University and \\ Economic Research Institute for ASEAN and East Asia (ERIA)
}

March 2016

\begin{abstract}
China, Japan, and Korea have been the three largest players in East Asian machinery production networks. This paper employs a new method of analysing finely disaggregated international trade data that applies the concept of zero trade flows, least-traded goods, and intensivelextensive margins of trade growth and scrutinises changes in the roles of China, Japan, and Korea in machinery production networks between 2007 and 2013. We find, first, that China became a dominant player in global machinery production networks in terms of both export values and the diversity and density of product-destination pairs. Second, the growth of Korea as machinery parts and components supplier was also salient and Korea's dependency on China rose sharply. Third, Japan continued to stagnate and machinery production links between Korea and Japan weakened substantially.
\end{abstract}

Keywords: zero trade; intensive and extensive margins; least-traded goods; productdestination pairs; machinery industry; parts and components trade JEL Classification: F14, F23

\footnotetext{
* The authors would like to thank the organisers and participants of the Inaugural International Conference, Centre on Asia and Globalisation, Lee Kuan Yew School of Public Policy, National University of Singapore held in Singapore on 16-17 September 2015, and in particular Prof. Tomoo Kikuchi.

$\dagger$ Ayako Obashi. Associate Visiting Scholar, Faculty of Economics, Keio University. 2-15-45 Mita, Minato-ku, Tokyo 108-8345, Japan. Phone: +81-3-5427-1574. E-mail: obashi@wisc.edu.

$\$$ Fukunari Kimura. Professor, Faculty of Economics, Keio University and Chief Economist, Economic Research Institute for ASEAN and East Asia (ERIA). 2-15-45 Mita, Minato-ku, Tokyo 108-8345, Japan. Phone: +81-3-3453-4511 (ext. 23215). E-mail: fkimura@econ.keio.ac.jp.
} 


\section{Introduction}

Since the 1990s, East Asia has led the world in the formation of production networks in machinery industries. ${ }^{1}$ In particular, China, Japan, and the Republic of Korea (henceforth, Korea) have continuously been important players in East Asia. Recently, however, we have observed drastic changes in the balance among these three countries. Their performances during the Global Financial Crisis differed widely. China conducted an unprecedented macro stimulus to maintain rapid economic growth. Korea took advantage of the Chinese boom and extended production networks. Japan remained stagnant and had to cope with various difficulties including natural and human-made disasters. It is thus worth reviewing the recent development of East Asian production networks, focusing on China, Japan, and Korea.

This paper sticks with international trade data and explores the analytical possibilities of recently developed empirical methods. We first separate machinery parts and components from machinery final products to be able to highlight the peculiarities of intermediate goods transactions. Subsequently, in addition to the traditional trade value approach, we apply the concepts of zero trade flows, leasttraded goods, and intensive and extensive margins of trade growth (Besedeš and Prusa, 2011; Debaere and Mostashari, 2010; Kehoe and Ruhl, 2013). This empirical approach is very effective in quantifying the development of production networks, and to assess how and to what degree countries participate in production networks.

In our companion paper on the Association of Southeast Asian Nations (ASEAN) (Obashi and Kimura, 2016), we traced the catching-up process of latecomers by measuring the degree of participation in production networks from the perspective of export product and destination diversification. In the cases of China, Japan, and Korea, we would like to provide an overview of competition and collaboration among these leading countries in the world in the formation of production networks. As we will show below, for China, Japan, Korea, and other big players in production networks, the export product mix was already fully diverse and

\footnotetext{
${ }^{1}$ East Asia here is defined as the so-called ASEAN+6 - the Association of Southeast Asian Nations (ASEAN) member countries, China, Japan, Korea, Australia, New Zealand, and India.
} 
saturated in the base year of our analysis. The concept of 'the proportion of non-zero to potential product-destination pairs' proposed by Baldwin and Harrigan (2011) is particularly useful in analysing big players in production networks. In this paper we emphasise counting the number of actually occurred, non-zero product-destination pairs relative to the number of potential pairs, the latter of which also differ across exporter countries. In addition, we employ the concept of 'least-traded goods' proposed by Kehoe and Ruhl (2013), which is useful for exploring the importance of the ins and outs of product-destination pairs, i.e. extensive margin, for big players in production networks by decomposing the growth in exports into intensive and extensive margins. We find contrasting performances in operating production networks in the three countries we examine.

This paper is structured as follows: the next section explains our laborious data construction to clean the data set. The third section develops the empirical analysis of the three countries' machinery export data. Starting with checking export/import shares of machinery parts and components and final products, we check the positioning of the three countries, ins and outs of export product-destination pairs, and extensive and intensive margins of export growth. The fourth section focuses on machinery trade among three countries. The last section concludes the paper.

\section{Data Description}

International trade data used throughout the paper are obtained from the United Nations (UN) Comtrade Database. We use import statistics, whenever they are available, as they are more reliable than export data. Most countries report country of origin as a partner in import statistics and last known destination as a partner in export statistics. Import statistics appear to be more reliable because the country of origin is more closely verified due to tariff regulations, even though the final destination may not be known at the time of export. 
We use import statistics for 2007 and 2013, based on the 1996 version of the Harmonized System (HS) product classification. ${ }^{2}$ To count the number of products traded and trading partner countries in a consistent manner, we restrict our attention to a group of 136 countries that are the UN member states and that report import statistics both for 2007 and 2013. In addition, we include a few East Asian countries including Brunei Darussalam, Lao PDR, and Myanmar, with some modifications: first, because Brunei did not report import statistics for 2007, we use those for 2006 instead. Second, Myanmar has reported trade statistics based on the HS classification, but only for 2001 and 2010, since 2000. Hence, we use Myanmar's import statistics for 2001 and 2010, instead of those for 2007 and 2013, respectively. Third, Lao PDR has reported trade statistics only for limited years, 1962-1974, based not on the HS classification, but on the Standard International Trade Classification (SITC; rev. 1). So instead we use export statistics reported by Lao PDR's trading partners, i.e. mirror data, for both 2007 and $2013 .^{3}$

By so doing, we are able to analyse all potential bilateral trade flows between $136+3=139$ countries, including all East Asian countries of interest, at two points in time, basically 2007 and 2013. In other words, we deal with 139 x 138 (= $139-1$ (the reporter country itself) $)=19,182$ potential exporter-importer pairs. ${ }^{4}$ By excluding the reporter country itself from a set of the partner countries, we remove obvious re-imports from our data set.

Based on the HS classification, manufactured goods range from HS 28 to HS 92. Among them, machinery includes all goods classified as part of general machinery

\footnotetext{
${ }^{2}$ The import statistics that we use are originally reported based on the HS 1996 classification or are converted to the HS 1996 classification if a country originally reported based on the other version of classification. We employ the HS 1996 classification though a substantial number of countries reported based on a newer version of classification even for 2007, because Indonesia, which is East Asian country of particular interest to the authors, reported based on the HS 1996 classification for 2007. The available annual data for 2014 already account for more than 90 percent of the world trade value, according to the UN Comtrade (accessed on 2015/10/16), and consist of a number of reporter countries; however, we use 2013 as the latest year of our analysis because Viet Nam, another East Asian country of interest, has yet to be included as a reporter in the data for 2014.

${ }^{3}$ See Appendix for a list of countries included in the data set.

${ }^{4}$ The aggregated total values of imports to the selected 136 reporter countries from 138 partner countries $(=136+3-1)$ account for more than 90 percent of annual total imports to all reporter countries available in the UN Comtrade Database from all partner countries with which ISO 3166-1 alpha-3 country codes are assigned, both for 2007 and 2013.
} 
(HS 84), electric machinery (HS 85), transport equipment (HS 86-89), and precision machinery (HS 90-92) industries. We group respective HS product codes, at the most disaggregated level, into machinery parts and components and final products. ${ }^{5}$

\section{China, Japan, and Korea and World Trade in Machinery}

Using highly disaggregated international trade data at the HS six-digit product level, we explore how and to what degree China, Japan, Korea, and other countries participate in international production networks in the machinery industry. In section 3.1, we begin with an analysis of the proportion of machinery parts and components in total exports and imports based on the traditional value data. The subsequent four sections then examine the degree of participation in production networks based on a novel approach of the diversification of products exported and export destination market countries, through revealing features of world exports of machinery from ten leading countries. After an initial overview using the value data in section 3.2, we count the number of exported products and destination markets in an informative way in sections 3.3 and 3.4. The importance of ins and outs of products and destinations in countries' exports is further explored by decomposing the export growth into intensive and extensive margins in section 3.5.

\subsection{Machinery Shares in Manufactures Exports and Imports}

To explore how and to what degree China, Japan, Korea, and other countries participate in international production networks, let us begin by comparing countries using the proportion of machinery parts and components in the total exports and imports of manufactured goods. In Figure 1, a pair of stacked bars shows the percentages of machinery in a country's manufactures exports to (the left bar) and imports from the world (the right bar). For each stacked bar, the dark-coloured portion represents the percentage accounted for by parts and components (labelled as ' $\mathrm{P} \& \mathrm{C}$ ') while the light colour portion represents the percentage accounted for by

\footnotetext{
${ }^{5}$ See Kimura and Obashi (2010) for the list of machinery parts and components at the HS (fourand) six-digit level for different versions of the HS classification.
} 
final products ('FP'). We focus on the 20 leading countries in world exports of machinery parts and components, including China, Japan, and Korea, which are selected based on the average value of exports in 2007 and 2013. The bars for the top 20 exporters are in descending order, from left to right, in terms of the machinery parts and components shares in exports.

\section{Figure 1: Machinery Shares in Total Manufactures Exports to and Imports}

\section{from the World}

Year 2007

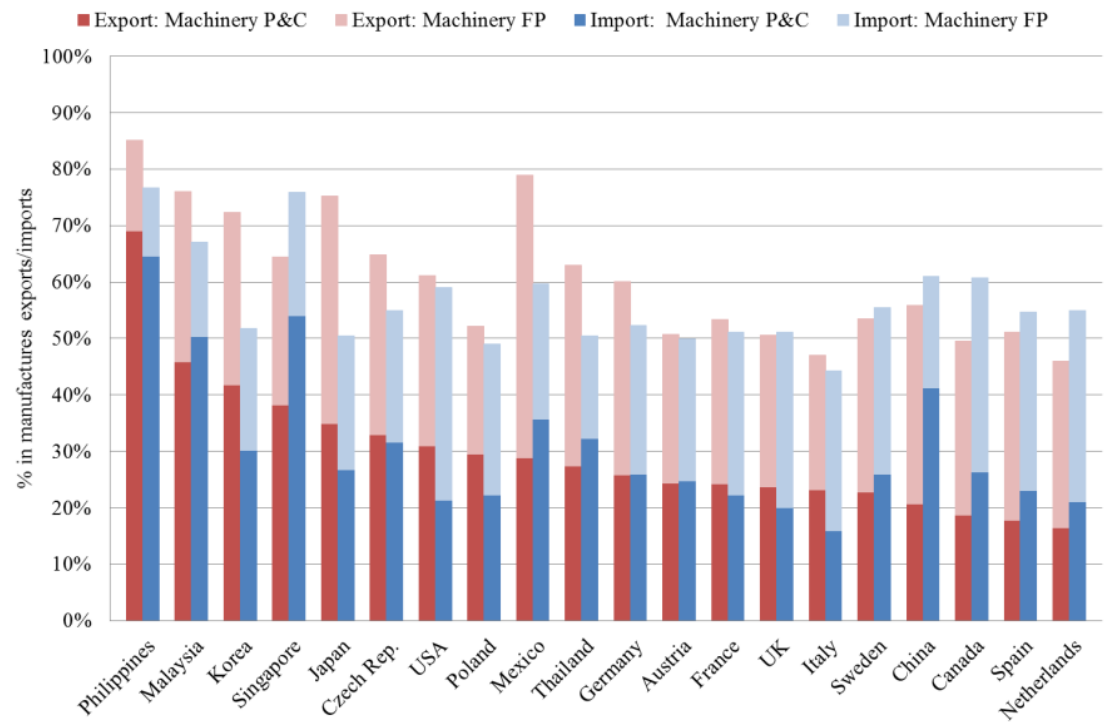

Year 2013

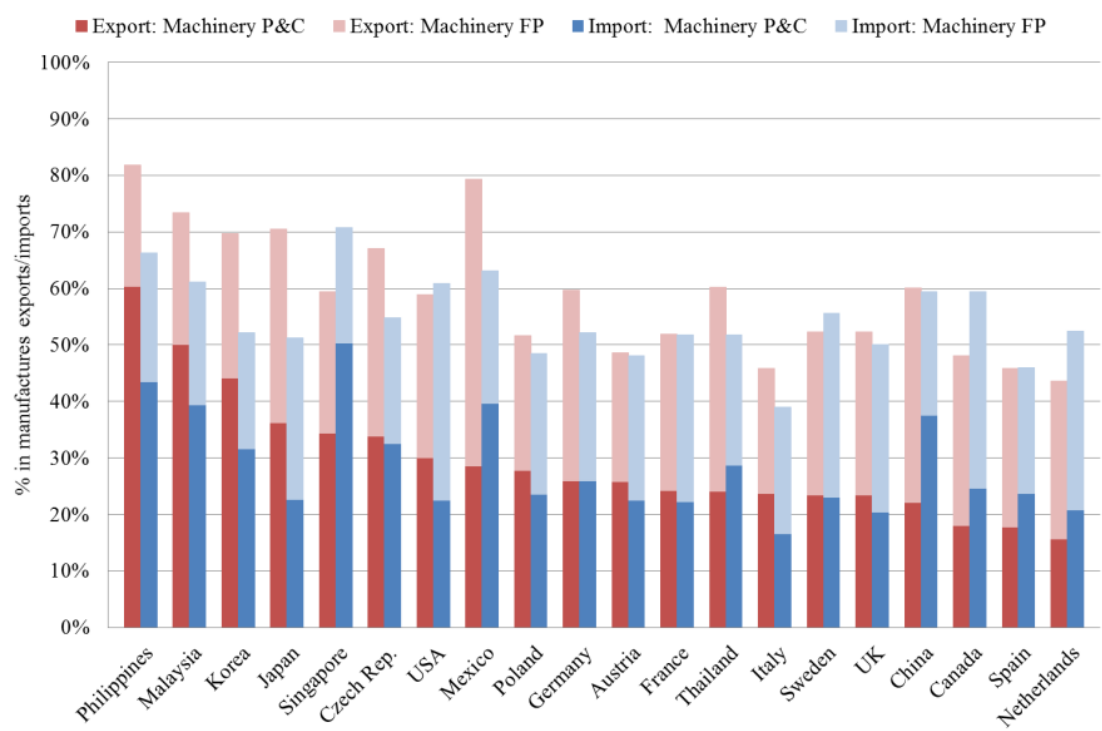


Notes: Machinery industries are defined as HS 84-92. Product groupings, i.e. parts and components (P\&C) and final products (FP), following Kimura and Obashi (2010). Top 20 exporter countries of machinery parts and components (selected based on the average export value in 2007 and 2013) are listed on the horizontal axis, in descending order, from left to right, in terms of the machinery parts and components shares in exports.

Source: UN Comtrade Database (mainly, import statistics reported by selected countries, based on the HS 1996 classification, at the six-digit level).

Figure 1 gives an overall picture of how the degree of integration into and the way of participating in international production networks differs even across the top 20 exporters. For China, for example, the percentage of machinery parts and components is about 20 percent in total manufactures exports; the corresponding percentage for imports is around 40 percent. The percentage of machinery final products is relatively high, compared with parts and components, ranging from 35 to 45 percent, for the export side. Similar patterns are observed for Mexico and Thailand. Such patterns can be considered as indicating these countries' role as the world's factory in the sense that they import a large amount of intermediate goods for the final assembly of products to be sold domestically or to be exported.

Korea, together with the Philippines and Malaysia, is one of the countries that have strikingly high percentages of machinery parts and components, exceeding 40 percent for the export side and 30 percent for the import side. The percentages accounted for by machinery final products, on the other hand, are relatively low. Such high percentages of machinery parts and components both for the export and import sides reflects these countries' active participation in back-and-forth transactions of intermediate goods across borders.

In addition to the Philippines, Malaysia, Korea, and Mexico, Japan is another country that is highly dependent on machinery exports. In contrast to Korea, the percentages of machinery final products in Japan's total manufactures exports and imports are very similar in magnitude to the corresponding figures for parts and components. Austria and France have a similar proportion of machinery final products to parts and components; however, it is striking that the relative importance of machinery in total exports from Japan is much higher than those countries' level, and is accompanied by a high percentage of machinery parts and components, exceeding 35 percent. 


\subsection{Ten Leading Countries in World Exports of Machinery}

In this and the following few subsections, we aim to elicit features of world trade in machinery, with special interest to China, Japan, and Korea, by focusing on leading countries in world exports of machinery parts and components and of machinery final products. For each of the product groupings, we select ten leading exporter countries in terms of the total value of exports to the world in 2013. Table 1 provides an initial overview of world exports of machinery. By product grouping, the values of exports in 2007 and 2013 and growth rates of export values between the two years are reported in the left part of the table. The cumulative shares in the total world trade of the product grouping concerned are in the rightmost column.

First and foremost, China achieves outstanding performance in exports of both machinery parts and components and final products. For machinery parts and components, China was ranked fourth, after the United States (US), Germany, and Japan, in 2007, but expanded exports by 51 percent, which is the highest rate of growth among the ten leading exporters, and has come out on top as of 2013. For machinery final products, China was already in the top spot in 2007, and further increased exports by 52 percent in the period from 2007 to 2013. In 2013, China led the value of exports of machinery final products by a large margin, achieving an export value 1.6 times higher than that of second-ranked Germany.

In contrast to China, the value of Japan's exports of machinery fell, especially for final products, by 22 percent, which is the lowest rate of (negative) growth among the ten leading exporters. For machinery parts and components, Japan's exports decreased slightly from 2007-13 and Korea's exports rose by 38 percent.

In 2013, both for machinery parts and components and for final products, the four largest exporter countries in the world were China, the US, Germany, and Japan. About a half of total world trade in machinery parts and components ( 47 percent) and in final products (51 percent) is accounted for by the four leading exporters. The ten leading exporters conduct more than 70 percent of world trade in machinery parts and components and in final products. 
Table 1: Overview of World Exports of Machinery

\begin{tabular}{|c|c|c|c|c|}
\hline \multirow{2}{*}{$\begin{array}{l}\text { Top } 10 \text { exporters of } \\
\text { machinery parts and components }\end{array}$} & \multicolumn{2}{|c|}{$\begin{array}{c}\text { Export value } \\
\text { (millions, constant US \$) }\end{array}$} & \multirow{2}{*}{$\begin{array}{l}\text { Growth } \\
\text { rate, } \\
2007-13\end{array}$} & \multirow{2}{*}{$\begin{array}{l}\text { Cumulative share in } \\
\text { the total world trade, } \\
\text { in } 2013\end{array}$} \\
\hline & 2007 & 2013 & & \\
\hline 1 China & 228,266 & 344,601 & $51 \%$ & $14 \%$ \\
\hline 2 USA & 292,682 & 301,182 & $3 \%$ & $26 \%$ \\
\hline 3 Germany & 287,146 & 281,220 & $-2 \%$ & $38 \%$ \\
\hline 4 Japan & 241,098 & 229,652 & $-5 \%$ & $47 \%$ \\
\hline 5 Korea & 140,333 & 193,299 & $38 \%$ & $55 \%$ \\
\hline 6 France & 106,967 & 97,254 & $-9 \%$ & $59 \%$ \\
\hline 7 Malaysia & 72,585 & 86,462 & $19 \%$ & $63 \%$ \\
\hline 8 Italy & 90,389 & 85,036 & $-6 \%$ & $66 \%$ \\
\hline 9 Mexico & 60,545 & 78,100 & $29 \%$ & $69 \%$ \\
\hline $10 \mathrm{UK}$ & 78,497 & 67,465 & $-14 \%$ & $72 \%$ \\
\hline \multirow{2}{*}{$\begin{array}{l}\text { Top } 10 \text { exporters of } \\
\text { machinery final products }\end{array}$} & \multicolumn{2}{|c|}{$\begin{array}{c}\text { Export value } \\
\text { (millions, constant US \$) }\end{array}$} & $\begin{array}{l}\text { Growth } \\
\text { rate, }\end{array}$ & $\begin{array}{l}\text { Cumulative share in } \\
\text { the total world trade, }\end{array}$ \\
\hline & 2007 & 2013 & $2007-13$ & in 2013 \\
\hline 1 China & 387,393 & 590,311 & $52 \%$ & $21 \%$ \\
\hline 2 Germany & 380,732 & 367,774 & $-3 \%$ & $33 \%$ \\
\hline 3 USA & 285,599 & 288,809 & $1 \%$ & $43 \%$ \\
\hline 4 Japan & 277,627 & 217,163 & $-22 \%$ & $51 \%$ \\
\hline 5 Mexico & 105,444 & 139,241 & $32 \%$ & $56 \%$ \\
\hline 6 Korea & 102,550 & 112,558 & $10 \%$ & $60 \%$ \\
\hline 7 France & 129,345 & 111,898 & $-13 \%$ & $64 \%$ \\
\hline $8 \mathrm{UK}$ & 89,422 & 83,353 & $-7 \%$ & $66 \%$ \\
\hline 9 Italy & 92,849 & 79,345 & $-15 \%$ & $69 \%$ \\
\hline 10 Netherlands & 78,031 & 72,013 & $-8 \%$ & $72 \%$ \\
\hline
\end{tabular}

UK = United Kingdom, US = United States.

Notes: See notes of Figure 1. By product grouping, top 10 exporter countries are listed in descending order, in terms of the export value in 2013. China, Japan, and Korea are countries of interest in the paper and are therefore highlighted. Export values are deflated by the consumer price index (CPI) in the US to obtain a constant dollar series, and are rounded off to the million. All figures expressed in percentage terms are rounded off to the whole number.

Source: UN Comtrade Database (mainly, import statistics reported by selected countries, based on the HS 1996 classification, at the six-digit level), IMF IFS Database (US CPI).

\subsection{Number of Export Products and Destinations}

Departing from simply looking at the value of trade, we turn our interest to counting the number of products traded and the number of trading partner countries 
and sorting out the pattern of export product and destination diversification. ${ }^{6}$ In addition to merely counting the numbers of exported products and destination market countries, we examine how many of potential export flows, i.e. product-destination pairs, a country is actually involved in. To do so, we follow Baldwin and Harrigan (2011) to define a zero at the most disaggregated level as a country's export flow that could have occurred but did not. That is, a zero occurs when a country exports a certain product at the HS six-digit level to at least one country but not to all countries in the sample. By so doing, zero export flows consist only of goods actually produced in the exporting country. Furthermore, in identifying a zero export flow, we restrict attention to destination countries to which the exporter country sells at least one product classified under the product grouping concerned. In other words, we exclude exporter-importer country pairs with no trade in the product grouping at all from our analysis. Actually occurred export flows are referred to as non-zeros.

In Figure 2, the light-coloured bars represent the numbers of non-zero productdestination pairs in countries' exports of machinery parts and components and of machinery final products to the world for 2007 and the dark-coloured bars for 2013 . The proportions of non-zero to potential product-destination pairs are reported on top of the corresponding bars. The numbers of products exported to at least one country and the numbers of destination market countries with non-zero trade of the product grouping concerned in 2007 and 2013 are in the lower part of the figure. The numbers of products classified under machinery parts and components and final products at the six-digit level of the HS 1996 classification are 445 and 729, respectively. And the maximum possible number of destination countries is 138 . As in Table 1, we focus on the 10 leading exporter countries for each product grouping, in terms of the total value of exports in 2013, and the top 10 exporters are listed in descending order, from left to right.

\footnotetext{
${ }^{6}$ Here we simply employ a cut-off of $\$ 0$ to determine whether a good is traded or not in a particular period, though employing an alternative cut-off when analysing the importance of the extensive (relative to intensive) margin of trade growth in sections 3.5 and 4.3.
} 


\section{Figure 2: Number of Products and Destinations in Machinery Exports}

\section{Machinery parts and components}

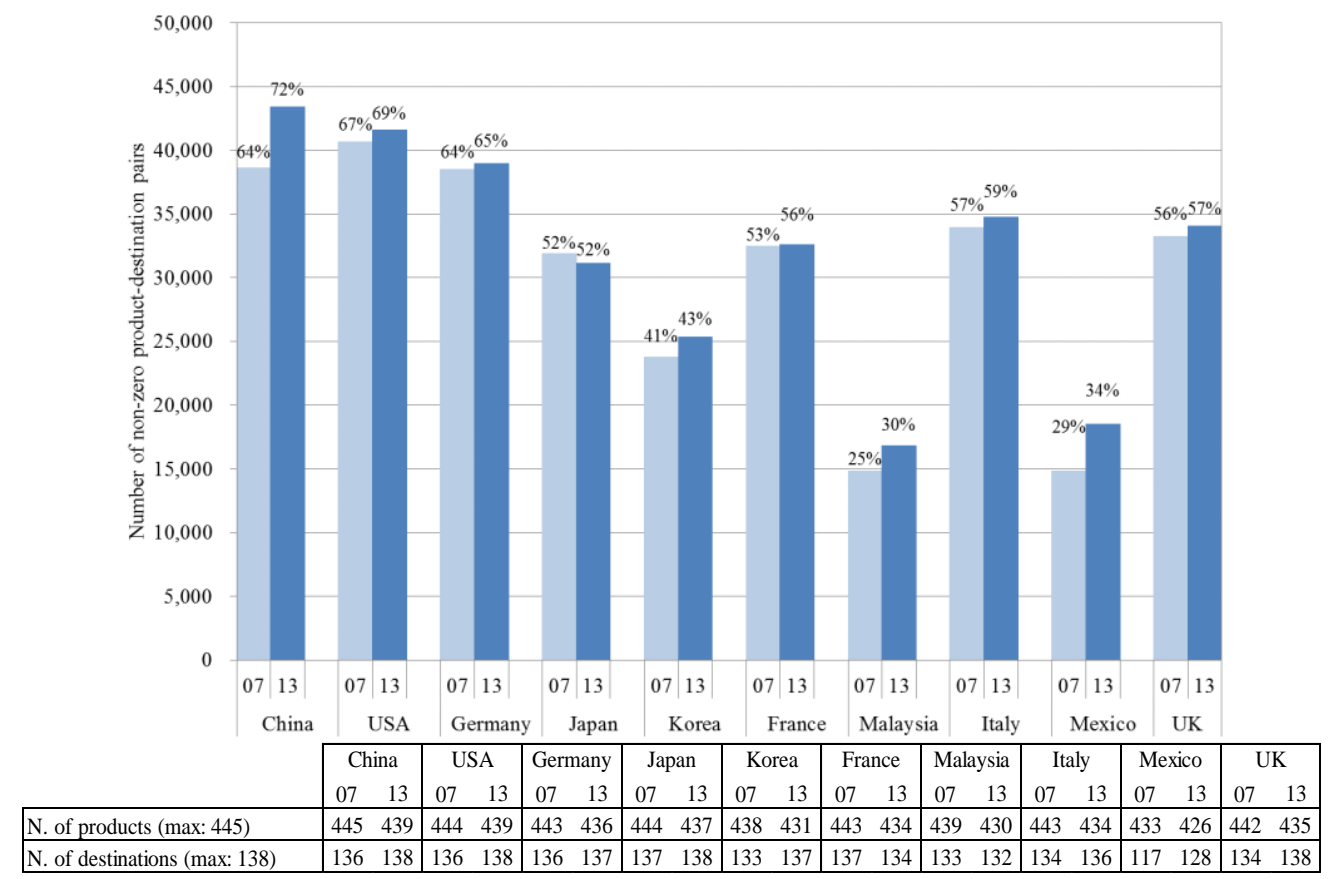

\section{Machinery final products}

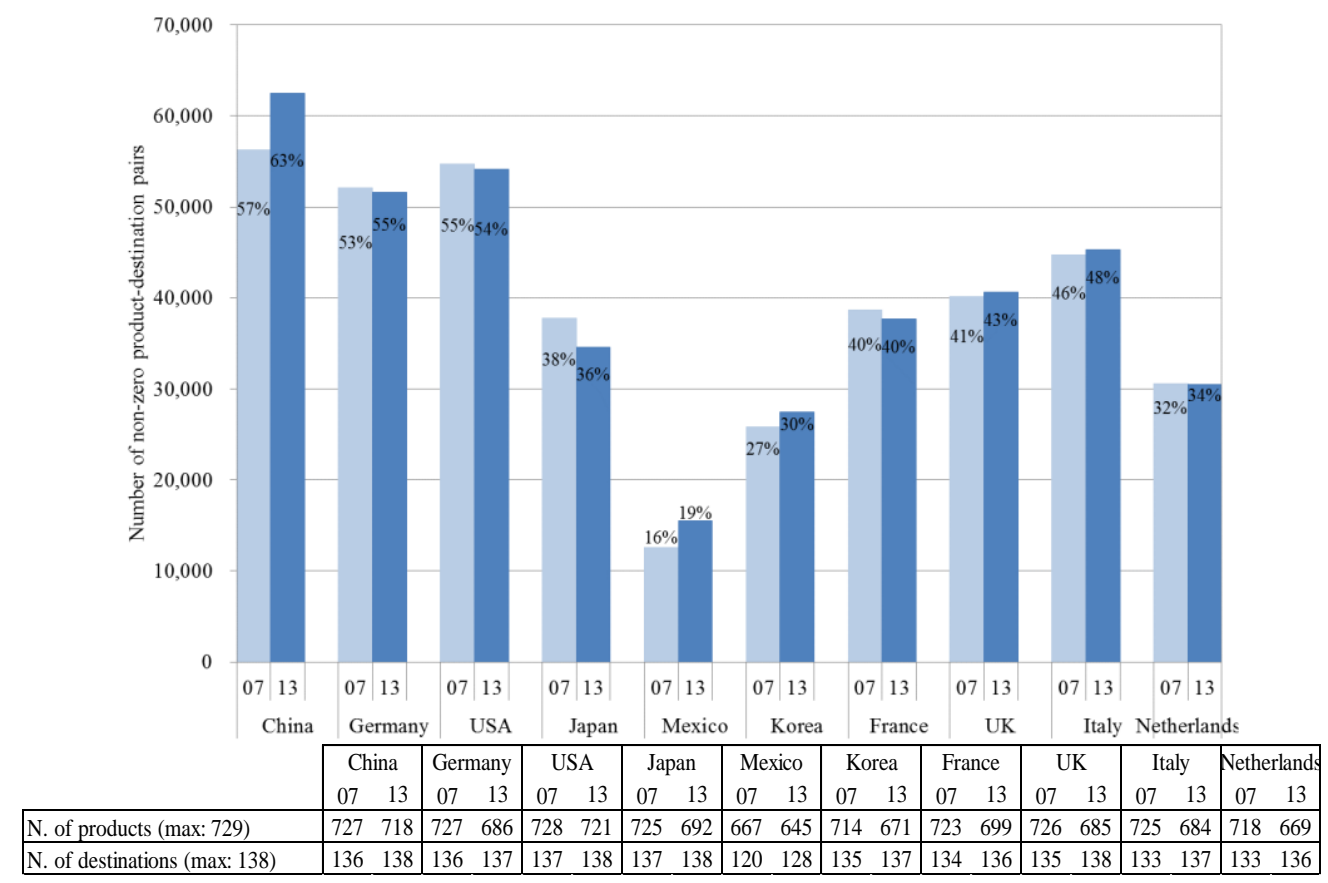

Notes: See notes of Figure 1. By product grouping, top 10 exporter countries are listed in descending order, from left to right, in terms of the export value in 2013. In order to count the number of products traded and trading partner countries, we employ a cut-off value of $\$ 0$ to determine whether or not a product is traded between a particular exporter-importer country pair. 
Source: UN Comtrade Database (mainly, import statistics reported by selected countries, based on the HS 1996 classification, at the six-digit level).

For all the 10 leading exporter countries, the number of machinery parts and components exported shows a slight decrease from 2007-13. The decrease in the number of machinery final products exported is much larger in magnitude. For machinery parts and components as well as final products, every country's export product mix appears to already hit the ceiling. Meanwhile, the number of destination countries in countries' exports of machinery parts and components trends upward for most of the ten countries except France and Malaysia. Similar upward trends in the diversification of destination countries are observed for exports of machinery final products from all the ten countries.

Despite the slight decrease in the number of products exported, the number of non-zero product-destination pairs in countries' exports of machinery parts and components has increased, driven by the diversification of destination countries, in the period 2007-2013 for all the countries except Japan. Reflecting the increase in the number of non-zero product-destination pairs, these countries, in contrast to Japan, experienced a rise in the percentage of non-zero product-destination pairs, which indicates that their export product-destination mix has become not only more geographically diverse but also denser. Similarly, the increase in the number of nonzero product-destination pairs and the simultaneous increase in the percentage of non-zero product-destination pairs are observed for exports of machinery final products from most countries, with the exceptions including not only Japan but also Germany and the US. Nevertheless, the most notable is Japan, whose export product-destination mix has become less diverse in the product space and less dense to the greatest extent, both for machinery parts and components and for final products.

China had a very high number of non-zero product-destination pairs, both in exports of machinery parts and components and of final products, already in 2007 and the number of pairs further increased sharply up to 2013. In 2013, China did not only lead the value of exports of machinery, but also the number and share of nonzero product-destination pairs. China has developed trade relationships of 43,410 and 62,443 product-destination pairs and is actually involved in 72 percent and 63 
percent of the potential product-destination pairs for machinery parts and components and for final products, respectively. The numbers of non-zero productdestination pairs in exports of machinery parts and components and of final products from China are 1.4 to 2.3 times higher than the level of Japan and Korea.

\subsection{Ins and Outs of Export Product-Destination Pairs}

Looking into changes in the number of (non-zero) product-destination pairs in countries' exports, Figure 3 reveals ins and outs of product-destination pairs that are occurring below the surface. A country experiences a change in the number of product-destination pairs, i.e. extensive margin, by exporting a new product that has never been exported or by exporting an already exported product to a new destination country to which the country had not previously exported the product. $^{7}$ Ins of product-destination pairs occur through entries of products to a country's export product mix or through entries of destinations to a country's product-specific destination mix. Similarly, outs of product-destination pairs occur through exits of products from a country's export product mix or through exits of destinations from a country's product-specific destination mix.

To be more precise, for exporter country $m$, define the set of non-zero productdestination pairs in period $t=\left\{t_{0}, t_{1}\right\}$ as $I^{m}$. Define the set of product-destination pairs with non-zero trade, i.e. being active, in both periods as $I^{m}=I^{m}{ }_{t 0} \cap I^{m}{ }_{t 1}$. Define the set of product-destination pairs that are active not in $t_{0}$ but in $t_{1}$ as $E N^{m}=I^{m}{ }_{t 1} \backslash I^{m}$, which corresponds to either (i) entries of products to country $m$ 's export product mix, $E N P^{m}$, or (ii) entries of destinations to country $m$ 's product-specific destination mix, $E N D^{m}$. Similarly, define the set of product-destination pairs that are active in $t_{0}$ but not in $t_{1}$ as $E X^{m}=I^{m}{ }_{t 0} \backslash I^{m}$, which corresponds to either (i) exits of products from country $m$ 's export product mix, $E X P^{m}$, or (ii) exits of destinations from country $m$ 's product-specific destination mix, $E X D^{m}$. Note that the number of non-zero product

\footnotetext{
${ }^{7}$ As far as the authors know, Besedeš and Prusa (2011) is one of few previous studies that examined changes in a country's exports to the world by decomposing the extensive margin into the new product margin and the new destination margin. We follow Besedeš and Prusa's way of thinking regarding the extensive margin. Other studies such as Kehoe and Ruhl (2013) focus only on the new product margin because they examine changes in trade patterns for a selected country pair.
} 
destination pairs in the base year equals the sum of continuing pairs and outs, $I^{m}{ }_{t 0}=$ $I^{m}+E X P^{m}+E X D^{m}$, while the number for the ending year is the sum of continuing pairs and ins, $I^{m}{ }_{t 1}=I^{m}+E N P^{m}+E N D^{m}$.

The stacked bars in Figure 3 show the composition of changes in the number of product-destination pairs in countries' exports of machinery parts and components and of machinery final products to the world between 2007 and 2013, by counting the number of pairs classified under the five different types: continuing, $I^{m}$; ins of products, $E N P^{m}$; ins of destinations, $E N D^{m}$; outs of products, $E X P^{m}$; and outs of destinations, $E X D^{m}$. As in Figure 2, the ten leading exporter countries are listed in descending order, from left to right.

For all the 10 leading exporter countries, a substantial amount of entries and exits of destinations to and from countries' product-specific destination mix of machinery parts and components and of final products are occurring below the surface. Meanwhile, no substantial amount of ins and outs of products is observed, reflecting the fact that every country's product mix was already fully diverse in the base year of 2007. For machinery parts and components, ins and outs of destinations reached levels ranging from 12 percent (Germany) to 49 percent (Malaysia) and from 8 percent (China) to 31 percent (Malaysia) of the number of continuing pairs, respectively. The corresponding figures for machinery final products are much larger: ins ranged from 18 percent (Germany) to 68 percent (Mexico) and outs from 13 percent (China) to 37 percent (Japan and Korea). These observations suggest that countries have undergone a non-negligible downsizing of the product-specific destination mix for some products while diversifying the destination mix for the other products, during a period of only six years.

In particular, the sharp increase in the number of product-destination pairs in China's exports of machinery parts and components and of final products is driven by a large amount of ins of destinations and a relatively small amount of outs of destinations, compared with other countries. The noticeable decrease in the number of product-destination pairs in Japan's exports of machinery, on the other hand, is driven by a large amount of outs and a limited amount of ins of destinations. 
Figure 3: Number of Product-Destination Pairs in Machinery Exports:

\section{Ins and Outs}

\section{Machinery parts and components}

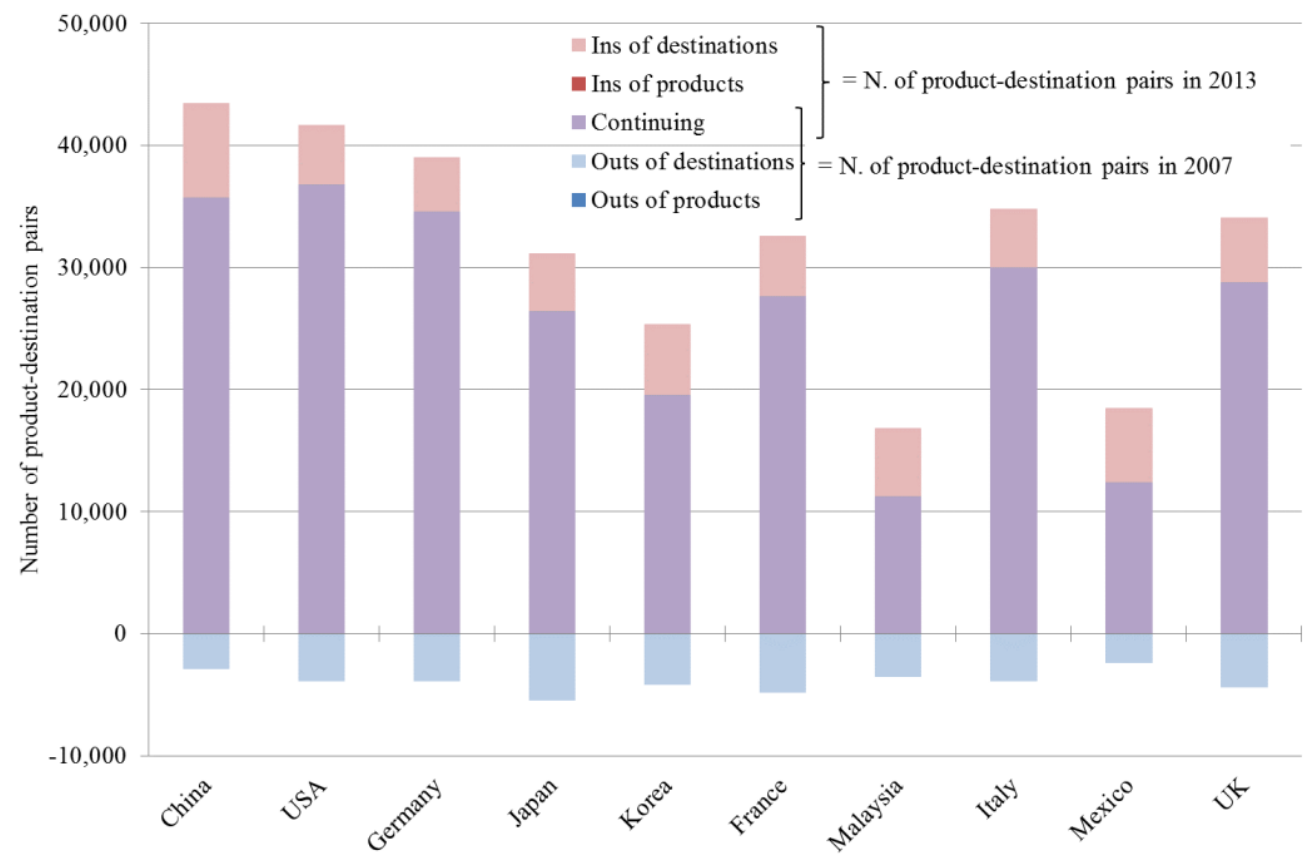

\section{Machinery final products}

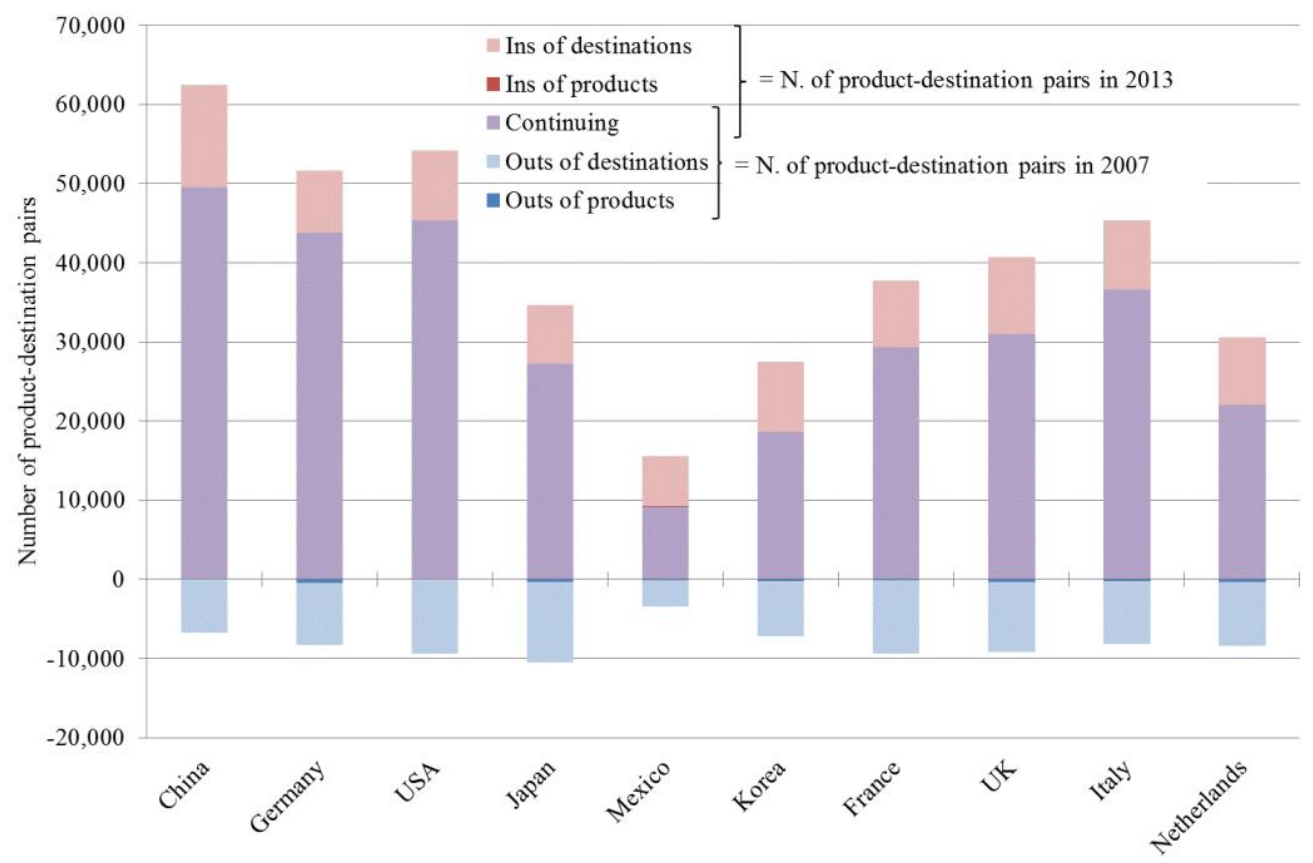

Note: See notes of Figure 2.

Source: UN Comtrade Database (mainly, import statistics reported by selected countries, based on the HS 1996 classification, at the six-digit level). 


\subsection{Intensive and Extensive Margins of Export Growth}

To further explore the relative importance of ins and outs of product-destination pairs in countries' exports, we decompose the growth in countries' total exports into intensive and extensive margins. In line with the methodology proposed by Kehoe and Ruhl (2013), we classify a good as not traded if its annual value of trade is zero or very low, instead of employing $\$ 0$ (as we did in sections 3.3. and 3.4) or other fixed cut-offs. For each exporter-importer country pair, we order goods from the smallest to the largest annual value of trade recorded for the base year, and create the set of least-traded goods (including goods that are not actually traded) so that the set accounts for cumulatively 10 percent of the total merchandise trade. We define the cut-off value of 'tradedness' to be the annual value of trade of the first good that would not be included in the set of least-traded goods for the base year. The set of least-traded goods in the ending year is made up of all the goods whose annual value of trade is less than the cut-off value defined above. In what follows, least-traded goods are regarded as 'non-traded' and the set of traded goods is simply the complement of the set of least-traded goods.

We then decompose the growth in country $m$ 's exports into contributions of the five different types of product-destination pairs discussed in section 3.4: $I^{m}, E N P^{m}$, $E N D^{m}, E X P^{m}$, and $E X D^{m}$. Once again, note that we here distinguish between traded and non-traded product-destination pairs, employing the cut-off $a$ la Kehoe and Ruhl (2013) that varies across exporter-importer country pairs, unlike the preceding subsections that deal with non-zero product-destination pairs and zeros by employing a cut-off of $\$ 0$. The country $m$ 's trade growth is decomposed as follows:

$$
\begin{aligned}
& \frac{\sum_{i \in I_{t_{1}}^{m}} x_{i, t_{1}}^{m}-\sum_{i \in I_{t_{0}}^{m}} x_{i, t_{0}}^{m}}{\sum_{i \in I_{t_{0}}^{m}} x_{i, t_{0}}^{m}}
\end{aligned}
$$

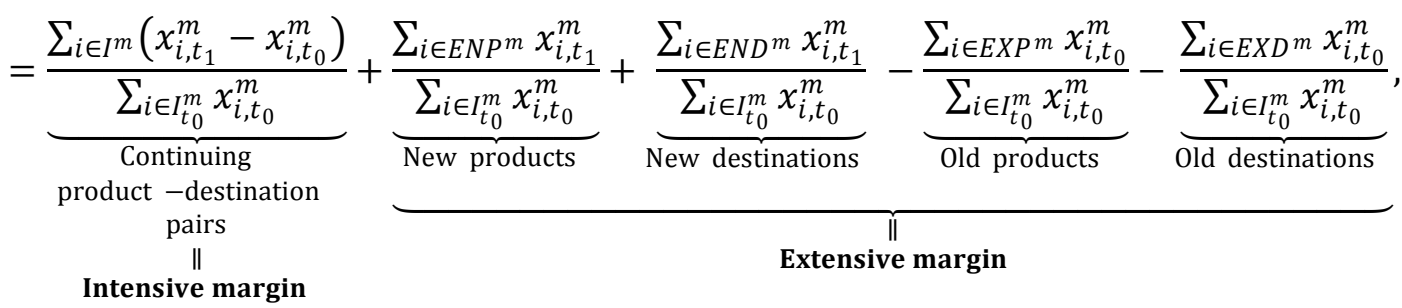


where the value of country $m$ 's exports for product-destination pair $i$ in period $t$ is denoted $x^{m}{ }_{i, t}$.

The stacked bars in Figure 4 show the contributions of the five different types of product-destination pairs to the growth in countries' exports of machinery parts and components and of machinery final products to the world from 2007-13. The diamond-shaped dot indicates the growth rate of the countries' total export values of the product grouping concerned from 2007-13. As in Figures 2 and 3, the top 10 exporter countries are listed in descending order, from left to right.

Overall, the growth in countries' exports of machinery parts and components and of final products is mostly attributed to the intensive margin. Although the growth contribution of the net extensive margin is limited relative to the intensive margin, looking into the contents of the extensive margin reveals non-negligible contributions of ins of new destinations and outs of old destinations to the total growth rate of exports of machinery below the surface though the contributions offset each other. In particular, although the total growth rates are limited or even negative in some cases, the US, Germany, Japan, and Italy experienced a substantial change in the composition of export values of machinery parts and components through the growth contribution of the turnover of destinations. Similarly, for Germany, the US, and the United Kingdom (UK), the turnover of destinations substantially affects the composition of export values of machinery final products. Notice that the (gross) growth contributions of new and old destinations are not necessarily consistent with the simple counting of ins and outs of destinations relative to the number of continuing product-destination pairs (explored in section 3.4 and Figure 3). 


\section{Figure 4: Decomposition of Growth in Machinery Exports: Intensive and Extensive Margins}

\section{Machinery parts and components}

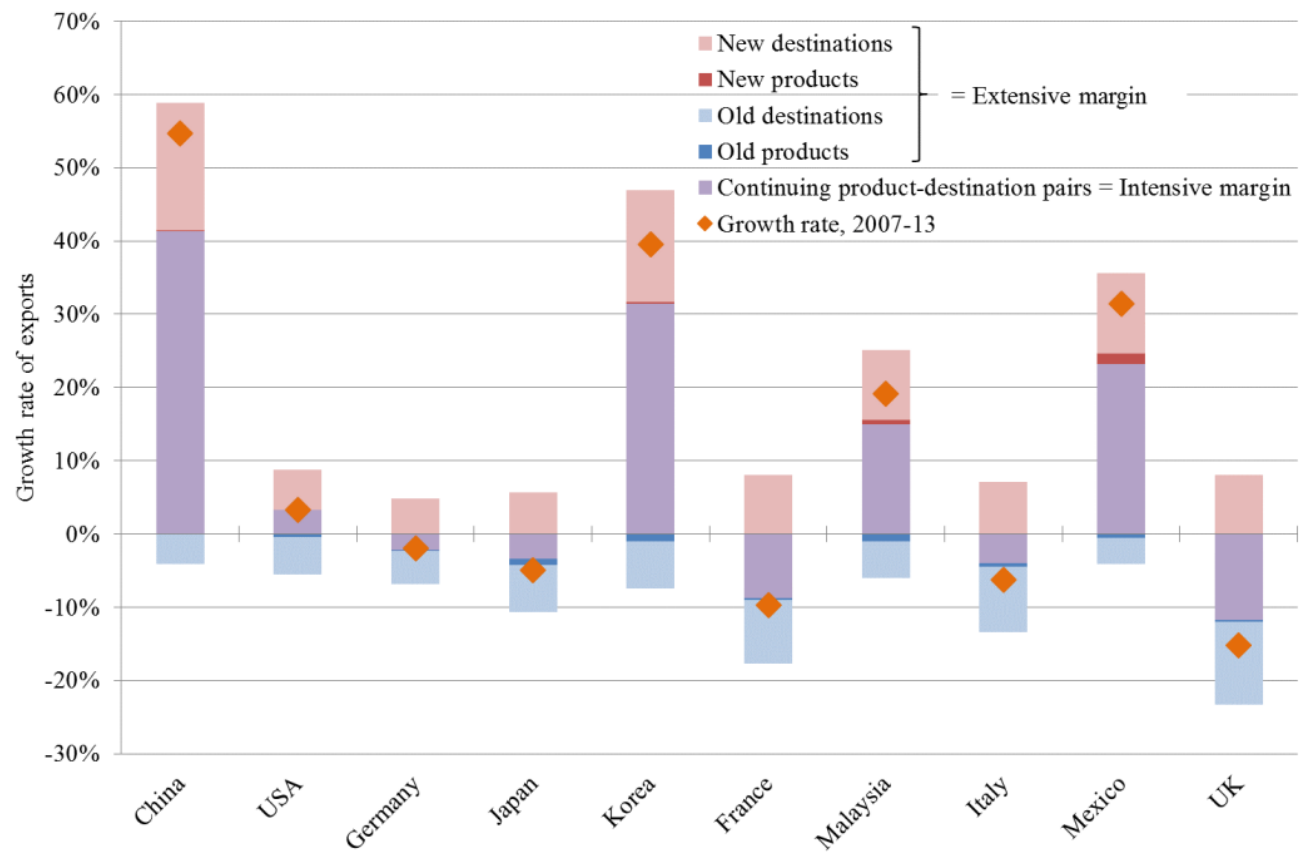

Machinery final products

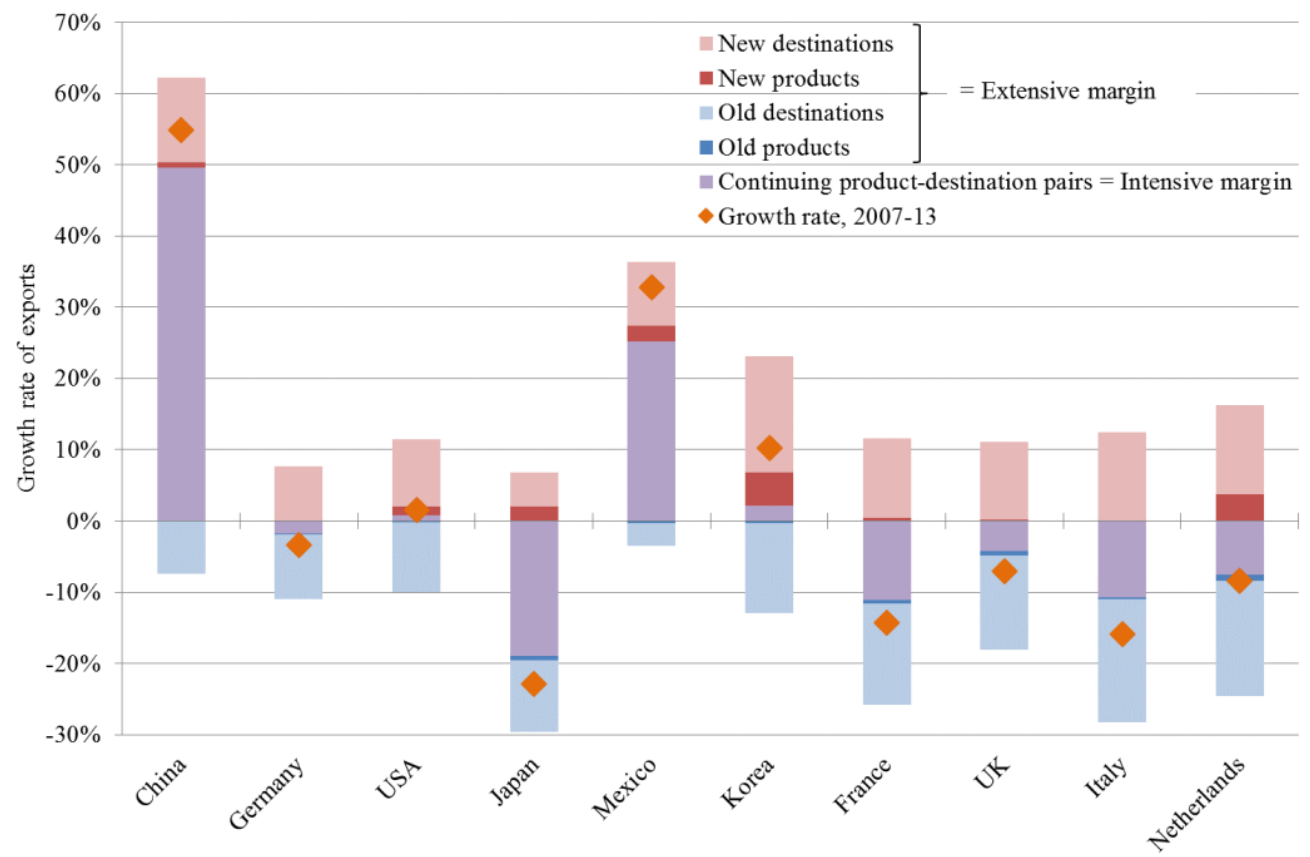

Notes: See notes of Figure 1. By product grouping, top 10 exporter countries are listed in descending order, from left to right, in terms of the export value in 2013. To determine whether or not a product is traded between a particular country pair in the base year of 2007, we employ Kehoe and Ruhl (2013)'s method of calculating cut-off values varying across exporter-importer country pairs. For each country pair, the same cut-off value is used to determine the 'tradedness' in the end-year of 2013.

Source: UN Comtrade Database (mainly, import statistics reported by selected countries, based on the HS 1996 classification, at the six-digit level). 
A notable exception is Korea, for which the (net) extensive margin makes up more than three-fourths of the total export growth rate (10 percent) in exports of machinery final products. More than half of the (net) extensive margin is accounted for by the product margin rather than by the destination margin. Nevertheless, the (gross) growth contributions of ins and outs of destinations are even larger though they offset each other. These observations suggest that Korea has undergone a drastic transformation of the composition of export values of machinery final products through ins and outs of economically important destinations with which Korea has a non-negligible amount of trade and by starting to export a non-negligible amount of new products.

\section{Trade in Machinery among China, Japan, and Korea}

In our data examinations of world trade in machinery, where we are especially interested in China, Japan, and Korea, we next explore how trade relationships between these big three exporter countries in the East Asian region have been changing. In section 4.1, we begin with an overview of intra-East Asian exports of machinery from the big three, showing the importance of intra-East Asian destination markets for their machinery exports as well as confirming their dominance of trade in machinery within the East Asian region. The following two subsections look into the changes in structure and margins of growth of bilateral trade within the big three by machinery subsectors.

\subsection{China, Japan, and Korea's Intra-East Asian Exports of Machinery}

Table 2 provides an overview of intra-East Asian exports of machinery from each country of the big three. By product grouping, the values of intra-East Asian exports in 2007 and 2013 and growth rates of export values between the two years are reported in the left part of the table. The proportions of intra-East Asian exports in countries' total exports of the product grouping concerned to the world are reported in the middle part of the table, followed by the cumulative shares in the total intra-East Asian trade of the product grouping concerned. For a reference, figures for 
bilateral trade within the big three are also reported for comparison with the aggregated regional figures. For each product grouping, the big three countries are listed in descending order, in terms of the total value of intra-East Asian exports in 2013.

Table 2: China, Japan, and Korea's Intra-East Asian Machinery Exports: Overview

Machinery parts and components

\begin{tabular}{|c|c|c|c|c|c|c|}
\hline & \multicolumn{2}{|c|}{$\begin{array}{c}\text { Export value } \\
\text { (millions, constant US \$) }\end{array}$} & \multirow{2}{*}{$\begin{array}{l}\text { Growth } \\
\text { rate, } \\
2007-13\end{array}$} & \multicolumn{2}{|c|}{$\begin{array}{l}\text { Share in country's total } \\
\text { exports to the world }\end{array}$} & \multirow{2}{*}{$\begin{array}{l}\text { Cumulative share in } \\
\text { the total intra-EA } \\
\text { trade, in } 2013\end{array}$} \\
\hline & 2007 & 2013 & & 2007 & 2013 & \\
\hline Korea's intra-EA exports & 89,996 & 137,877 & $53 \%$ & $64 \%$ & $71 \%$ & $25 \%$ \\
\hline to China & 59,877 & 98,478 & $64 \%$ & $43 \%$ & $51 \%$ & \\
\hline to Japan & 11,678 & 7,043 & $-40 \%$ & $8 \%$ & $4 \%$ & \\
\hline China's intra-EA exports & 83,966 & 131,302 & $56 \%$ & $37 \%$ & $38 \%$ & $48 \%$ \\
\hline to Japan & 27,370 & 32,807 & $20 \%$ & $12 \%$ & $10 \%$ & \\
\hline to Korea & 17,890 & 25,703 & $44 \%$ & $8 \%$ & $7 \%$ & \\
\hline Japan's intra-EA exports & 123,884 & 125,849 & $2 \%$ & $51 \%$ & $55 \%$ & $71 \%$ \\
\hline to China & 62,980 & 63,692 & $1 \%$ & $26 \%$ & $28 \%$ & \\
\hline to Korea & 16,534 & 15,755 & $-5 \%$ & $7 \%$ & $7 \%$ & \\
\hline
\end{tabular}

Machinery final products

\begin{tabular}{|c|c|c|c|c|c|c|}
\hline & \multicolumn{2}{|c|}{$\begin{array}{c}\text { Export value } \\
\text { (millions, constant US \$) }\end{array}$} & \multirow{2}{*}{$\begin{array}{l}\text { Growth } \\
\text { rate, } \\
2007-13\end{array}$} & \multicolumn{2}{|c|}{$\begin{array}{l}\text { Share in country's total } \\
\text { exports to the world }\end{array}$} & \multirow{2}{*}{$\begin{array}{l}\text { Cumulative share in } \\
\text { the total intra-EA } \\
\text { trade, in } 2013\end{array}$} \\
\hline & 2007 & 2013 & & 2007 & 2013 & \\
\hline China's intra-EA exports & 81,690 & 144,695 & $77 \%$ & $21 \%$ & $25 \%$ & $42 \%$ \\
\hline to Japan & 28,766 & 51,472 & $79 \%$ & $7 \%$ & $9 \%$ & \\
\hline to Korea & 9,895 & 13,331 & $35 \%$ & $3 \%$ & $2 \%$ & \\
\hline Japan's intra-EA exports & 73,556 & 74,061 & $1 \%$ & $26 \%$ & $34 \%$ & $64 \%$ \\
\hline to China & 27,807 & 31,899 & $15 \%$ & $10 \%$ & $15 \%$ & \\
\hline to Korea & 12,475 & 8,755 & $-30 \%$ & $4 \%$ & $4 \%$ & \\
\hline Korea's intra-EA exports & 21,263 & 32,326 & $52 \%$ & $21 \%$ & $29 \%$ & $73 \%$ \\
\hline to China & 8,117 & 15,677 & $93 \%$ & $8 \%$ & $14 \%$ & \\
\hline to Japan & 2,682 & 3,947 & $47 \%$ & $3 \%$ & $4 \%$ & \\
\hline
\end{tabular}

Notes: See notes of Figure 1 and Table 1. East Asia here consists of ASEAN+6. By product grouping, exporter countries are listed in descending order, in terms of the intra-East Asian export value in 2013.

Source: UN Comtrade Database (mainly, import statistics reported by selected countries, based on the HS 1996 classification, at the six-digit level), IMF IFS Database (US CPI).

First of all, Table 2 confirms the dominance of the big three exporter countries over the trade in machinery within the East Asian region. The big three exporters as a whole made up 71 percent of total intra-East Asian trade in machinery parts and 
components and 73 percent of total intra-East Asian trade in machinery final products in 2013.

The most notable change in intra-East Asian exports of machinery from the big three is that China and Korea greatly expanded their exports, by more than 50 percent, whereas Japan's exports remained stagnant from 2007-13. Such contrasting growth rates between rapidly growing China and Korea and a stagnant Japan are similar to what we observed for their total exports to the world in section 3.2 (and Table 1). For intra-East Asian trade in machinery parts and components, Japan has been displaced by rapidly growing Korea and China as the top exporters. As of 2013, intra-East Asian exports of machinery parts and components from the big three countries are comparable in value to each other. For machinery final products, on the other hand, China has remained in first place, leaving the other two far behind. In 2013, intra-East Asian exports of machinery final products from China were twice as large as Japan's exports in value terms. The value of intra-East Asian exports of machinery final products from Korea was still less than half of Japan's exports though Korea showed strong growth in 2007-13.

All the big three countries tended to increase their intra-East Asian exports at a more rapid rate than their exports to the rest of the world, resulting in the growing importance of intra-East Asian destination markets. Most notably, the share of intraEast Asian trade in the overall exports of machinery parts and components from Korea to the world was 64 percent in 2007 and further increased to a strikingly high level of 71 percent in 2013. For machinery final products, Japan was the most highly dependent on intra-East Asian destination markets, with its share of intra-East Asian trade increasing from 26 percent in 2007 to 34 percent in 2013.

Comparing figures for bilateral trade between the big three with the aggregated regional figures reveals that Korea expanded exports of machinery parts and components, becoming increasingly dependent on China rather than intra-East Asian destination markets in general. The share of exports to China in the overall exports of machinery parts and components from Korea to the world was 43 percent in 2007 and rose to 51 percent in 2013. That is, more than 70 percent of Korea's intra-East Asian exports of machinery parts and components was shipped to China in 2013. In contrast, despite the high growth in intra-East Asian exports and overall exports to 
the world, Korea's exports of machinery parts and components to Japan decreased by 40 percent. As a result, the share of exports to Japan in the overall exports of machinery parts and components from Korea to the world was only 4 percent in 2013. Similarly, Japan's exports of machinery parts and components and of final products became increasingly dependent on China as a destination and its trade relationship with Korea weakened.

\subsection{Overview by Machinery Subsector}

Looking into bilateral trade in the machinery subsectors among China, Japan, and Korea, we examine how these big three countries have constructed trade relationships with each other and how the trade patterns among them changed from 2007-13. In the left part of Table 3, the values of trade in 2007 and 2013 and the growth rates of trade values between the two years are reported for respective exporter-importer country pairs between the big three, by machinery subsector and by product grouping. The proportions of trade between the exporter-importer country pairs in the exporter countries' total exports to the world in the sectorproduct grouping concerned are reported in the middle part of the table. The numbers of products traded in 2007 and 2013, the numbers of those traded in both years, i.e. continuing products, the numbers of those traded not in 2007 but in 2013, i.e. ins of products, and the numbers of those traded in 2007 but not in 2013, i.e. outs of products, are on the right side of the table. The number of products classified under each sector-product grouping, i.e. the maximal possible number of products traded, is noted on the top row of the corresponding section of the table. By sector-product grouping, exporter-importer country pairs are listed in descending order, in terms of the value of trade in 2013 .

First, electric machinery parts and components make up 40 percent of total bilateral trade in machinery between the big three in 2013. The most notable feature of trade in electric machinery parts and components among the big three is an increase of transactions between China and Korea. On the one hand, Korea's exports to China expanded by 94 percent, whereas its exports to Japan decreased by almost half ( -46 percent) from 2007-13. Korea's exports to China became more than twice as large as Japan's exports to China, which ceded the top spot to Korea's exports to 
China in 2013. On the other hand, China's exports to Korea increased at a higher rate (47 percent) than its exports to Japan (22 percent). As a result, China's exports to Korea outweighed its exports to Japan in 2013.

Table 3: Machinery Trade among China, Japan, and Korea: Overview

\begin{tabular}{|c|c|c|c|c|c|c|c|c|c|c|}
\hline & \multicolumn{2}{|c|}{$\begin{array}{c}\text { Trade value } \\
\text { (millions, constant US \$) }\end{array}$} & \multirow{2}{*}{$\begin{array}{c}\text { Growth } \\
\text { rate, } \\
2007-13 \\
\end{array}$} & \multicolumn{2}{|c|}{$\begin{array}{l}\text { Share in country's total } \\
\text { exports to the world }\end{array}$} & \multicolumn{5}{|c|}{$\mathrm{N}$. of products } \\
\hline & 2007 & 2013 & & 2007 & 2013 & 2007 & 2013 & Continuing & Ins & Outs \\
\hline \multicolumn{6}{|c|}{ General machinery parts and components } & \multicolumn{5}{|c|}{$(\max : 186)$} \\
\hline Japan to China & 12,091 & 14,381 & $19 \%$ & $15 \%$ & $18 \%$ & 176 & 173 & 170 & 3 & 6 \\
\hline China to Japan & 9,539 & 10,358 & $9 \%$ & $10 \%$ & $9 \%$ & 165 & 164 & 159 & 5 & 6 \\
\hline Korea to China & 7,587 & 6,689 & $-12 \%$ & $29 \%$ & $24 \%$ & 164 & 165 & 159 & 6 & 5 \\
\hline Japan to Korea & 4,264 & 4,924 & $15 \%$ & $5 \%$ & $6 \%$ & 179 & 176 & 175 & 1 & 4 \\
\hline China to Korea & 3,834 & 3,902 & $2 \%$ & $4 \%$ & $3 \%$ & 172 & 175 & 169 & 6 & 3 \\
\hline Korea to Japan & 2,395 & 2,222 & $-7 \%$ & $9 \%$ & $8 \%$ & 161 & 157 & 151 & 6 & 10 \\
\hline \multicolumn{6}{|c|}{ General machinery final products } & \multicolumn{5}{|c|}{ (max: 325$)$} \\
\hline China to Japan & 13,574 & 19,513 & $44 \%$ & $8 \%$ & $8 \%$ & 267 & 270 & 252 & 18 & 15 \\
\hline Japan to China & 15,196 & 12,181 & $-20 \%$ & $21 \%$ & $23 \%$ & 293 & 288 & 280 & 8 & 13 \\
\hline Korea to China & 4,325 & 7,458 & $72 \%$ & $18 \%$ & $27 \%$ & 272 & 266 & 254 & 12 & 18 \\
\hline China to Korea & 4,051 & 5,645 & $39 \%$ & $2 \%$ & $2 \%$ & 270 & 292 & 264 & 28 & 6 \\
\hline Japan to Korea & 6,659 & 3,455 & $-48 \%$ & $9 \%$ & $7 \%$ & 278 & 276 & 260 & 16 & 18 \\
\hline Korea to Japan & 946 & 719 & $-24 \%$ & $4 \%$ & $3 \%$ & 228 & 226 & 201 & 25 & 27 \\
\hline \multicolumn{6}{|c|}{ Electric machinery parts and components } & \multicolumn{5}{|c|}{ (max: 144) } \\
\hline Korea to China & 35,255 & 68,412 & $94 \%$ & $43 \%$ & $55 \%$ & 131 & 125 & 124 & 1 & 7 \\
\hline Japan to China & 37,990 & 32,473 & $-15 \%$ & $36 \%$ & $38 \%$ & 134 & 131 & 131 & 0 & 3 \\
\hline China to Korea & 12,159 & 17,880 & $47 \%$ & $11 \%$ & $10 \%$ & 133 & 130 & 130 & 0 & 3 \\
\hline China to Japan & 14,172 & 17,307 & $22 \%$ & $13 \%$ & $10 \%$ & 131 & 129 & 128 & 1 & 3 \\
\hline Japan to Korea & 9,222 & 7,740 & $-16 \%$ & $9 \%$ & $9 \%$ & 130 & 130 & 127 & 3 & 3 \\
\hline Korea to Japan & 7,145 & 3,876 & $-46 \%$ & $9 \%$ & $3 \%$ & 127 & 124 & 120 & 4 & 7 \\
\hline \multicolumn{6}{|c|}{ Electric machinery final products } & \multicolumn{5}{|c|}{ (max: 149) } \\
\hline China to Japan & 11,974 & 27,691 & $131 \%$ & $6 \%$ & $10 \%$ & 107 & 108 & 106 & 2 & 1 \\
\hline China to Korea & 4,981 & 6,002 & $20 \%$ & $3 \%$ & $2 \%$ & 110 & 113 & 110 & 3 & 0 \\
\hline Japan to China & 5,501 & 5,533 & $1 \%$ & $14 \%$ & $19 \%$ & 111 & 107 & 106 & 1 & 5 \\
\hline Korea to China & 2,306 & 3,623 & $57 \%$ & $7 \%$ & $12 \%$ & 102 & 95 & 91 & 4 & 11 \\
\hline Korea to Japan & 1,516 & 2,905 & $92 \%$ & $4 \%$ & $9 \%$ & 98 & 100 & 94 & 6 & 4 \\
\hline Japan to Korea & 1,999 & 1,424 & $-29 \%$ & $5 \%$ & $5 \%$ & 108 & 110 & 107 & 3 & 1 \\
\hline \multicolumn{6}{|c|}{ Transport equipment parts and components } & \multicolumn{5}{|c|}{ (max: 44) } \\
\hline Japan to China & 4,727 & 7,023 & $49 \%$ & $14 \%$ & $16 \%$ & 39 & 38 & 37 & 1 & 2 \\
\hline Korea to China & 1,373 & 3,173 & $131 \%$ & $14 \%$ & 18 & 31 & 35 & 30 & 5 & 1 \\
\hline China to Japan & 1,428 & 2,691 & $89 \%$ & $10 \%$ & $10 \%$ & 37 & 37 & 34 & 3 & 3 \\
\hline China to Korea & 619 & 1,257 & $103 \%$ & $4 \%$ & $4 \%$ & 37 & 40 & 36 & 4 & 1 \\
\hline Korea to Japan & 432 & 749 & $73 \%$ & $4 \%$ & $4 \%$ & 31 & 29 & 28 & 1 & 3 \\
\hline Japan to Korea & 1,111 & 624 & $-44 \%$ & $3 \%$ & $1 \%$ & 41 & 38 & 37 & 1 & 4 \\
\hline \multicolumn{6}{|c|}{ Transport equipment final products } & & & (max: 88) & & \\
\hline Japan to China & 3,794 & 7,281 & $92 \%$ & $3 \%$ & $7 \%$ & 55 & 47 & 42 & 5 & 13 \\
\hline Korea to China & 848 & 2,208 & $160 \%$ & $2 \%$ & $5 \%$ & 36 & 34 & 25 & 9 & 11 \\
\hline China to Japan & 1,042 & 1,225 & $18 \%$ & $6 \%$ & $4 \%$ & 45 & 52 & 37 & 15 & 8 \\
\hline Japan to Korea & 1,890 & 1,166 & $-38 \%$ & $1 \%$ & $1 \%$ & 58 & 58 & 52 & 6 & 6 \\
\hline China to Korea & 425 & 774 & $82 \%$ & $2 \%$ & $3 \%$ & 50 & 53 & 43 & 10 & 7 \\
\hline Korea to Japan & 45 & 45 & $0 \%$ & $0 \%$ & $0 \%$ & 40 & 40 & 30 & 10 & 10 \\
\hline Precision machiner & arts and com & & & & & & & $(\max : 71)$ & & \\
\hline Korea to China & 15,663 & 20,204 & $29 \%$ & $68 \%$ & $85 \%$ & 56 & 56 & 54 & 2 & 2 \\
\hline Japan to China & 8,172 & 9,815 & $20 \%$ & $44 \%$ & $50 \%$ & 63 & 62 & 61 & 1 & 2 \\
\hline China to Korea & 1,278 & 2,664 & $108 \%$ & $11 \%$ & $16 \%$ & 63 & 63 & 62 & 1 & 1 \\
\hline Japan to Korea & 1,937 & 2,468 & $27 \%$ & $10 \%$ & $12 \%$ & 59 & 58 & 57 & 1 & 2 \\
\hline China to Japan & 2,232 & 2,451 & $10 \%$ & $19 \%$ & $14 \%$ & 66 & 63 & 63 & 0 & 3 \\
\hline Korea to Japan & 1,706 & 196 & $-89 \%$ & $7 \%$ & $1 \%$ & 56 & 47 & 47 & 0 & 9 \\
\hline Precision machiner & inal products & & & & & & & (max: 167) & & \\
\hline Japan to China & 3,316 & 6,905 & $108 \%$ & $15 \%$ & $23 \%$ & 142 & 135 & 132 & 3 & 10 \\
\hline China to Japan & 2,175 & 3,043 & $40 \%$ & $11 \%$ & $10 \%$ & 138 & 134 & 127 & 7 & 11 \\
\hline Japan to Korea & 1,927 & 2,710 & $41 \%$ & $9 \%$ & $9 \%$ & 141 & 138 & 135 & 3 & 6 \\
\hline Korea to China & 637 & 2,389 & $275 \%$ & $22 \%$ & $36 \%$ & 124 & 118 & 111 & 7 & 13 \\
\hline China to Korea & 437 & 910 & $108 \%$ & $2 \%$ & $3 \%$ & 139 & 143 & 136 & 7 & 3 \\
\hline Korea to Japan & 175 & 278 & $59 \%$ & $6 \%$ & $4 \%$ & 114 & 99 & 90 & 9 & 24 \\
\hline
\end{tabular}

$\mathrm{N} .=$ number, $\max =$ maximum.

Notes: See notes of Figure 1 and Table 1. Machinery includes general machinery (HS 84), electric machinery (HS 85), transport equipment (HS 86-89), and precision machinery (HS 90- 
92). By machinery subsector and by product grouping, exporter-importer country pairs are listed in descending order, in terms of the trade value in 2013.

Source: UN Comtrade Database (mainly, import statistics reported by selected countries, based on the HS 1996 classification, at the six-digit level).

Similar trends can be observed for trade in transport equipment and in precision machinery, both for parts and components and for final products. For those other than trade in precision machinery parts and components, however, Japan's exports to China also have increased steadily and are still more than twice as large as Korea's exports to China in 2013.

Second, China's exports to Japan remained in the lead in bilateral trade in electric machinery final products among the big three and further increased by 131 percent from 2007-13. As of 2013, China's exports of electric machinery final products to Japan are more than four times as high as second-ranked China's exports to Korea in value terms. Korea's exports of electric machinery final products to Japan also showed strong growth (92 percent) though their value remained relatively limited in 2013. In addition, China's exports of general machinery final products to Japan increased steadily from 2007-13 and had the highest value in bilateral trade between the big three in 2013 .

Third, bilateral trade in general machinery parts and components between the big three show a different picture of Japan's presence as an exporter. In addition to the fact that Japan's exports to China continued to lead by a substantial margin, Japan's exports of general machinery parts and components to China and Korea achieved higher growth than other exporter-importer country pairs from 2007-13.

Lastly, the numbers of machinery parts and components actually exported bilaterally from one country to another among the big three tend to be large relative to the maximal possible number, compared with the numbers of final products traded relative to the maximal possible number. In particular, the numbers of electric machinery parts and components and of precision machinery parts and components bilaterally traded between the big three appear to have already peaked, showing a slight downward trend from 2007-13. Additionally, an increasing number of products traded is noticeable for exporter-importer country pairs including China in the sample period. For machinery parts and components, bilateral exports to China 
tended to increase the number of products exported to a greater extent, compared with other bilateral export flows; for machinery final products, bilateral exports from China tended to increase the number of products exported to a greater extent, compared with other bilateral export flows.

\subsection{Intensive and Extensive Margins of Trade Growth}

We further explore the relative importance of ins and outs of products in bilateral trade among China, Japan, and Korea. In an analogous way to what we did in section 3.5 (and Figure 4), we decompose the growth of bilateral trade in machinery, by subsector and by product grouping, into intensive and extensive margins. The stacked bars in Figure 5 show the contributions of continuing products, new products, and old products to growth in bilateral trade of the sector-product groupings concerned from 2007-13. The diamond indicates the growth rate of the exporter-importer country pair's total trade value of the product grouping concerned from 2007-13. As in Table 3, for each sector-product grouping, exporter-importer country pairs are listed in descending order, from left to right, in terms of the value of trade in 2013.

Figure 5: Machinery Trade among China, Japan, and Korea: Intensive and Extensive Margins of Trade Growth

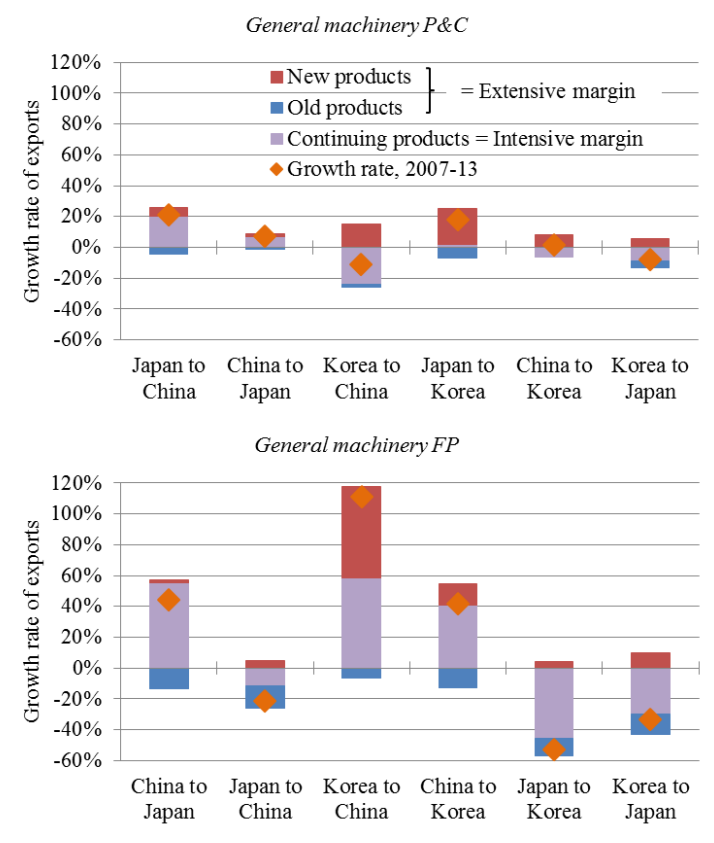



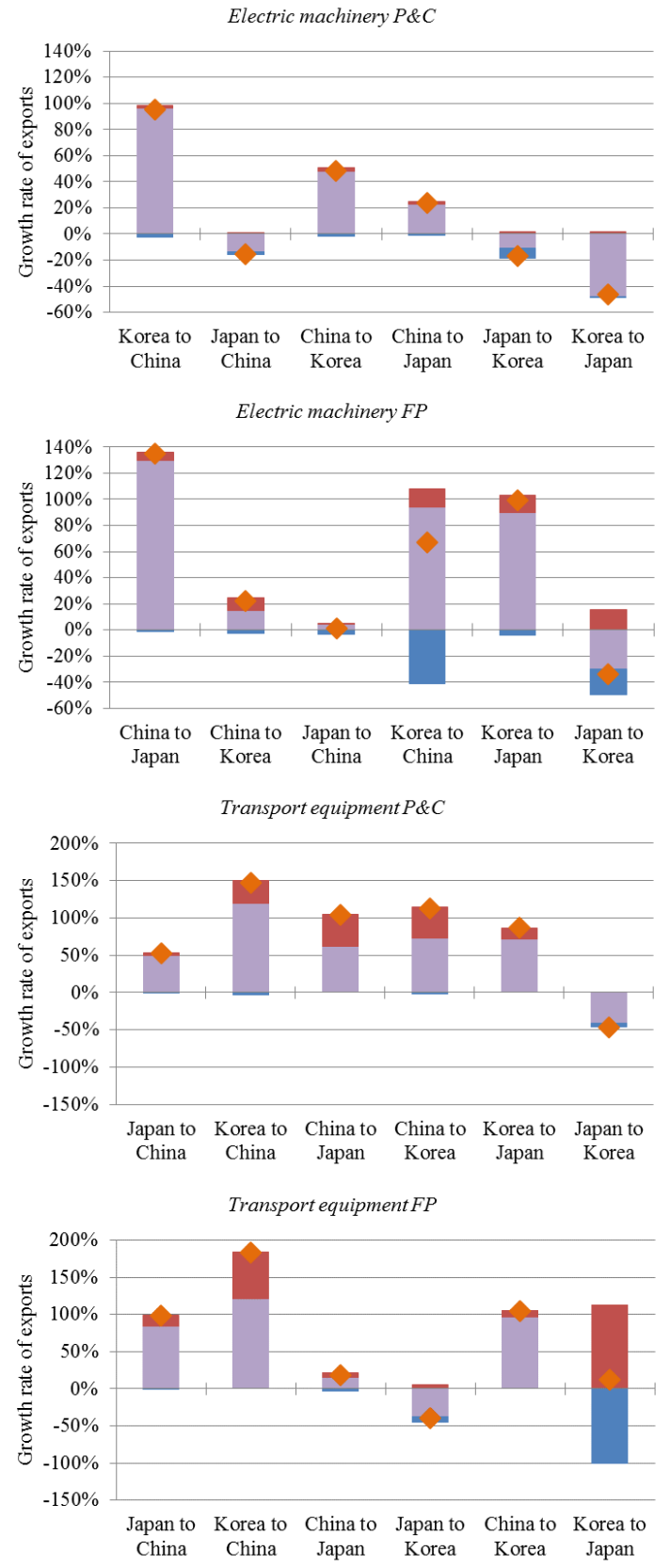

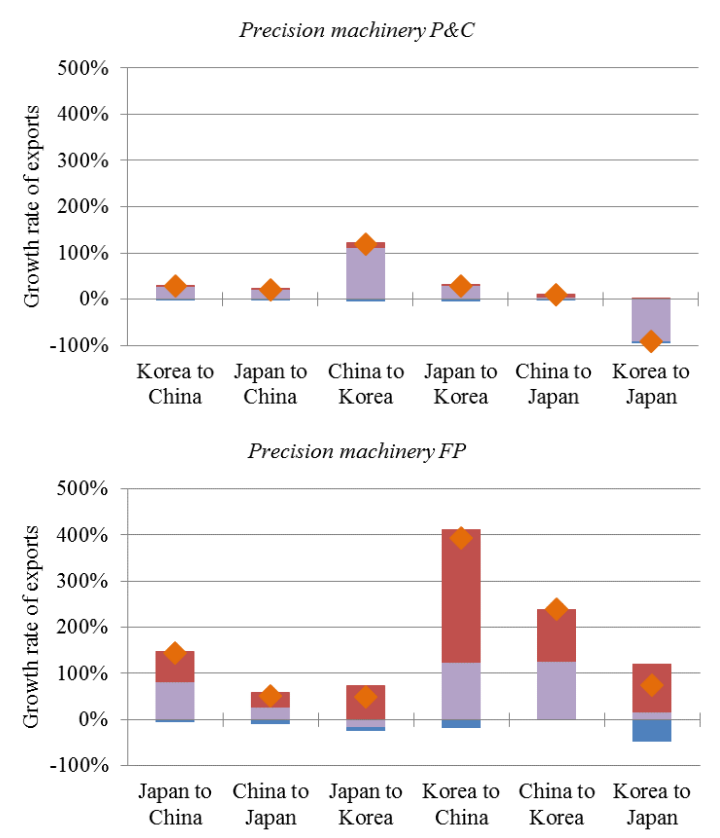

Notes: See notes of Figure 4. Machinery includes general machinery (HS 84), electric machinery (HS 85), transport equipment (HS 86-89), and precision machinery (HS 90-92). By machinery subsector and by product grouping, exporter-importer country pairs are listed in descending order, from left to right, in terms of the trade value in 2013.

Source: UN Comtrade Database (mainly, import statistics reported by selected countries, based on the HS 1996 classification, at the six-digit level).

The growth of bilateral trade in machinery parts and components between the big three was mostly attributed to the intensive margin from 2007-13, with the exception of Japan's exports of general machinery parts and components to Korea. The (net) extensive margin accounted for about 90 percent of total growth in Japan's exports of general machinery parts and components to Korea, which suggests that Japan steadily increased exports to Korea through export product diversification, or by starting to export a non-negligible amount of new products. The relative importance of the extensive margin, particularly of the growth contribution of ins of new products, could also be observed for China's exports of transport equipment parts and components to Japan and to Korea to a relatively limited extent.

Compared with trade growth in machinery parts and components, growth of bilateral trade in final products between the big three tended to be accounted for by the intensive margin to a lesser extent. In particular, about half or more of total trade growth in precision machinery final products was attributed to the (net) extensive margin rather than the intensive margin. The most prominent example was the notably high growth (393 percent) in Korea's exports of precision machinery final 
products to China, which is attributed largely to ins of new products (287 out of 393 percent points, or more than 70 percent of total growth). The growth in Korea's exports of general machinery final products to China is also driven by export product diversification to a considerable extent. It is also worth noting that the (gross) growth contributions of ins and outs of products are very large, though they almost totally offset each other, in Korea's exports of transport equipment final products to Japan. Behind the resulting low growth rate of the trade value, Korea appears to have undergone a drastic transformation of the composition of its exports of transport equipment final products to Japan through ins and outs of economically important products.

\section{Conclusion}

This paper employs the newly developed analytical method of zero trade flows, least-traded goods, and intensive and extensive margins of trade growth and analyses the recent changes in machinery production networks extended by China, Japan, and Korea between 2007 and 2013. Our empirical approach has proved to be very effective in terms of shedding light on the structure and evolution of production networks. We found drastic changes in East Asian production networks within this rather short period. China became the main player in machinery production networks, not only in trade values but also in the diversity and density of export product-destination pairs. Although the outstanding growth of China's machinery exports could be mostly attributed to the intensive margin, China actively built more trade relationships of existing products with new destination countries. Korea took advantage of China's dynamism and extended its production networks, and it also underwent a drastic transformation in product and destination composition of exports of machinery final products. Japan remained stagnant and its relative position deteriorated in the regional as well as global context.

These results have profound policy implication. First, the dominant position of China in production networks means that China has become increasingly influential worldwide. Of course, exports and imports by China are not wholly accounted for by 
Chinese firms; the role of multinational enterprises including Japanese and Korean firms is still substantial in China's international trade. Nevertheless, the importance of China as a centre of production networks is clear. This implies, for example, that the recent slowdown of the Chinese economy may potentially have a much larger impact than before on countries that are connected with China through production networks. Another concern is China's passive attitude toward mega-free trade agreements (FTAs). Mega-FTAs are now regarded as important policy channels to improve the international business environment for production networks through establishing high standards of trade/investment liberalisation and a prototype for new international rules. However, in the negotiations on the Regional Comprehensive Economic Partnership (RCEP) or ASEAN+6 FTA, China, together with India, has continuously tried to keep the liberalisation level as low as possible. As a result, the Economic Ministers Meeting held in August 2015 set the modality of negotiation with a tariff removal ratio of only 80 percent. It was bad timing, because just after this, in October 2015, the Trans-Pacific Economic Partnership (TPP) negotiation reached a broad agreement. China is now a responsible player in production networks and thus should proactively involve itself in the establishment of a new international economic order for production networks.

Second, Korea has achieved a lot of progress in terms of its participation in production networks though it has become much more dependent on China. Korean chaebols, when extending their production networks in China and other parts of East Asia, tend to maintain most of their input-output relationships and connections with Korean partner firms rather than switching to more efficient foreign firms. This means that Korean firms might be less prone to being influenced by the performance of Chinese firms than Japanese firms. However, in the past few years, the growth of the Korean economy seems to have decelerated due to the slowdown of China. Production links between Korea and China should be investigated further at the micro level.

Third, Japan's poor performance from 2007-13 was due to various negative shocks, such as the Global Financial Crisis, the Great East Japan Earthquake, the strong appreciation of the yen, and confusing economic policies. Since the end of 2012, 'Abenomics' has been effective in terms of returning to the '2007 normal', but 
it does not seem to have raised the potential growth rate of the Japanese economy. Although manufacturing employment is still sustained at least in medium and largescale firms, the nature of activities that remain in Japan must be scrutinised.

\section{References}

Baldwin, R. and J. Harrigan (2011), 'Zeros, Quality, and Space: Trade Theory and Trade Evidence', American Economic Journal: Microeconomics, 3(2), pp.60-88. doi: 10.1257/mic.3.2.60

Besedeš, T. and T.J. Prusa (2011), 'The Role of Extensive and Intensive Margins and Export Growth', Journal of Development Economics, 96, pp.371-79. doi:10.1016/j.jdeveco.2010.08.013

Debaere, P. and S. Mostashari (2010), 'Do Tariffs Matter for the Extensive Margin of International Trade?, An Empirical Analysis', Journal of International Economics, 81, pp.163-69. doi:10.1016/j.jinteco.2010.03.005

Kehoe, T.J. and K.J. Ruhl (2013), 'How Important is the New Goods Margin in International Trade?', Journal of Political Economy, 121, pp.358-92. doi:10.1086/670272

Kimura, F. and A. Obashi (2010), International Production Networks in Machinery Industries: Structure and its Evolution', ERIA Discussion Paper Series ERIA-DP-2010-09. Jakarta: Economic Research Institute for ASEAN and East Asia (ERIA). Avaiable at: http://www.eria.org/ERIA-DP-2010-09.pdf

Obashi, A. and F. Kimura (2016), Deepening and Widening of Production Networks in ASEAN. Manuscript submitted for publication. 


\section{Appendix}

Table A1: Countries Included in the Data Set

\begin{tabular}{|c|c|c|c|c|}
\hline \multicolumn{5}{|c|}{ Reporters of import statistics based on the HS 1996 classification for 2007 and 2013 (136 countries) } \\
\hline Albania & China & India & Morocco & Senegal \\
\hline Algeria & Colombia & Indonesia* & Mozambique & Serbia \\
\hline Andorra & Congo & Ireland & Namibia & Singapore \\
\hline Antigua and Barbuda* & Costa Rica & Israel & Netherlands & Slovakia \\
\hline Argentina & Côte d'Ivoire & Italy & New Zealand & Slovenia \\
\hline Armenia & Croatia & Jamaica & Nicaragua & Solomon Isds \\
\hline Australia & Cyprus & Japan & Niger & South Africa \\
\hline Austria & Czech Rep. & Jordan & Nigeria & Spain \\
\hline Azerbaijan & Denmark & Kazakhstan & Norway & Sri Lanka \\
\hline Bahamas & Dominican Rep. & Kenya & Oman & Sweden \\
\hline Bahrain & Ecuador & Kiribati & Pakistan & Switzerland \\
\hline Barbados & El Salvador & Kuwait & Palau & TFYR of Macedonia \\
\hline Belarus & Estonia & Kyrgyzstan & Panama & Thailand \\
\hline Belgium & Ethiopia & Latvia & Paraguay & Togo \\
\hline Belize & Fiji & Lebanon & Peru & Tunisia \\
\hline Benin & Finland & Lithuania & Philippines & Turkey \\
\hline Bolivia & France & Luxembourg & Poland & Uganda \\
\hline Bosnia Herzegovina & FS Micronesia & Madagascar & Portugal & Ukraine* \\
\hline Botswana* & Gambia* & Malawi & Qatar & United Kingdom \\
\hline Brazil & Georgia & Malaysia & Rep. of Korea & United Rep. of Tanzania \\
\hline Bulgaria & Germany & Maldives & Rep. of Moldova & Uruguay \\
\hline Burkina Faso & Ghana & Malta & Romania & USA \\
\hline Burundi & Greece & Mauritania* & Russian Federation & Venezuela \\
\hline Cabo Verde & Guatemala & Mauritius & Rwanda & Viet Nam \\
\hline Cambodia & Guyana & Mexico & Samoa* & Yemen \\
\hline Canada & Hungary & Mongolia & Sao Tome and Principe* & Zambia \\
\hline $\begin{array}{l}\text { Central African Rep. } \\
\text { Chile }\end{array}$ & Iceland & Montenegro & Saudi Arabia & Zimbabwe \\
\hline
\end{tabular}

Countries included in our sample with modification (3 countries)

Brunei Darussalam (whose import statistics for 2006 are used instead of those for 2007)

Lao People's Dem. Rep. (for which export statistics reported by trade partners are used)

Myanmar (whose import statistics for 2001 and 2010 are used instead of those for 2007 and 2013 )

Notes: The country names listed above follow abbreviations used in the UN Comtrade Database (our source of data). * indicates that a country originally reported based on the HS 1996 classification for 2007 (this is not applicable to 2013 for all the listed countries). For countries without $*$, we use converted data. China includes only mainland China. Because the statistical territory of China's external trade statistics coincides with its customs territory that does not cover the separate customs territories of Hong Kong and Macau, the UN Comtrade Database practically treats mainland China and those Special Administrative Regions (SARs) separately. France includes Monaco. Norway includes Svalbard and Jan Mayen. Switzerland includes Liechtenstein. USA includes Puerto Rico and US Virgin Islands.

Source: Authors. 
ERIA Discussion Paper Series

\begin{tabular}{|c|c|c|c|}
\hline No. & Author(s) & Title & 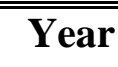 \\
\hline 2016-10 & $\begin{array}{l}\text { Ayako OBASHI and } \\
\text { Fukunari KIMURA }\end{array}$ & $\begin{array}{l}\text { The Role of China, Japan, and Korea } \\
\text { in Machinery Production Networks }\end{array}$ & $\begin{array}{l}\text { Mar } \\
2016\end{array}$ \\
\hline 2016-09 & $\begin{array}{l}\text { Ayako OBASHI and } \\
\text { Fukunari KIMURA }\end{array}$ & $\begin{array}{l}\text { Deepening and Widening Production } \\
\text { Networks in ASEAN }\end{array}$ & $\begin{array}{l}\text { Mar } \\
2016\end{array}$ \\
\hline 2016-08 & Willem THORBECKE & $\begin{array}{l}\text { Increasing the Resilience of Asian } \\
\text { Supply Chains to Natural Disasters: } \\
\text { The Role of the Financial Sector }\end{array}$ & $\begin{array}{l}\mathrm{Feb} \\
2016\end{array}$ \\
\hline 2016-07 & $\begin{array}{l}\text { Hiroyuki NAKATA, } \\
\text { Yasuyuki SAWADA } \\
\text { and Kunio SEKIGUCHI }\end{array}$ & $\begin{array}{l}\text { Market Concentration and Risk- } \\
\text { Prevention Incentives: The Case of } \\
\text { the Hard Disk Drive Industry }\end{array}$ & $\begin{array}{c}\text { Feb } \\
2016\end{array}$ \\
\hline 2016-06 & Meinhard BREILING & $\begin{array}{l}\text { Tourism Supply Chains and Natural } \\
\text { Disasters: The Vulnerability } \\
\text { Challenge and Business Continuity } \\
\text { Models for ASEAN Countries }\end{array}$ & $\begin{array}{l}\mathrm{Feb} \\
2016\end{array}$ \\
\hline 2016-05 & $\begin{array}{l}\text { Masaru TANAKA and } \\
\text { Shigeatsu } \\
\text { HATAKEYAMA }\end{array}$ & $\begin{array}{l}\text { Towards Reframing the Spirit of } \\
\text { ASEAN Environmentalism: Insights } \\
\text { from Japan's COHHO Experience } \\
\text { and Studies }\end{array}$ & $\begin{array}{l}\text { Feb } \\
2016\end{array}$ \\
\hline 2016-04 & $\begin{array}{l}\text { Manaek SM } \\
\text { PASARIBU }\end{array}$ & $\begin{array}{l}\text { Challenges of Indonesian } \\
\text { Competition Law and Some } \\
\text { Suggestions for Improvement }\end{array}$ & $\begin{array}{l}\text { Jan } \\
2016\end{array}$ \\
\hline $2016-03$ & $\begin{array}{l}\text { VO Tri Thanh and } \\
\text { NGUYEN Anh Duong }\end{array}$ & $\begin{array}{l}\text { Promoting Rural Development, } \\
\text { Employment, and Inclusive Growth in } \\
\text { ASEAN }\end{array}$ & $\begin{array}{l}\text { Jan } \\
2016\end{array}$ \\
\hline 2016-02 & $\begin{array}{l}\text { Venkatachalam } \\
\text { ANBUMOZHI }\end{array}$ & $\begin{array}{l}\text { Convergence of Opportunities: } \\
\text { Resilience and the ASEAN } \\
\text { Community }\end{array}$ & $\begin{array}{l}\text { Jan } \\
2016\end{array}$ \\
\hline
\end{tabular}




\begin{tabular}{cllc}
\hline \hline No. & \multicolumn{1}{c}{ Author(s) } & \multicolumn{1}{c}{ Title } & Year \\
\hline \hline \multirow{2}{*}{$2016-01$} & Lili Yan ING, Shujiro & How Do Exports and Imports Affect & \\
& URATA and Yoshifumi & the Use of Free Trade Agreements? & Jan \\
& FUKUNAGA & $\begin{array}{l}\text { Firm-level Survey Evidence from } \\
\text { Southeast Asia }\end{array}$ & 2016 \\
\hline
\end{tabular}

Previous year of ERIA Discussion Paper, can be downloaded at:

http://www.eria.org/publications/discussion_papers/FY2015/ http://www.eria.org/publications/discussion_papers/FY2014/ http://www.eria.org/publications/discussion_papers/FY2013/ http://www.eria.org/publications/discussion_papers/FY2012/ http://www.eria.org/publications/discussion_papers/FY2011/ http://www.eria.org/publications/discussion_papers/FY2010/ http://www.eria.org/publications/discussion_papers/FY2009/ http://www.eria.org/publications/discussion_papers/FY2008/ 